
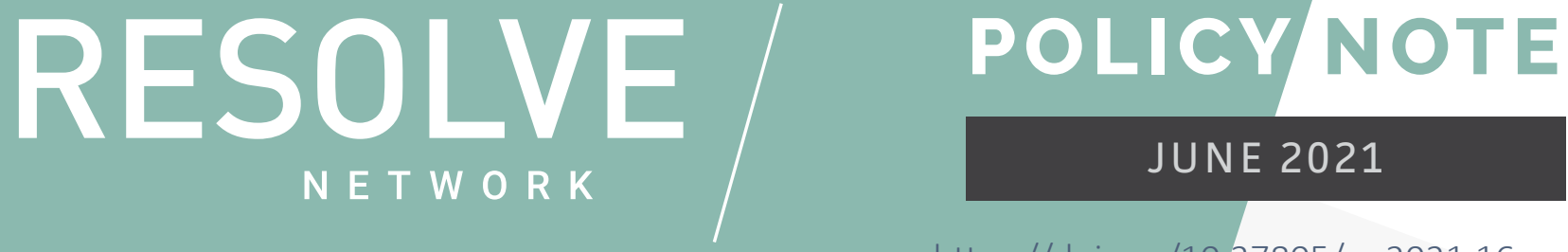

https://doi.org/10,37805/pn2021.16.vedr

\title{
WHOSE VULNERABILITY? TRAUMA RECOVERY IN THE REINTEGRATION OF FORMER VIOLENT EXTREMISTS
}

\author{
MICHAEL NICONCHUK
}

VIOLENT EXTREMIST

DISENGAGEMENT AND RECONCILIATION

${ }^{66}$ Research in global mental health confirms trauma is not only relevant to the emergence of violent extremism but is also a consequence of participation in violent extremism.

\section{FAST FACTS}

$\rightarrow$ Social ecological and trauma-informed approaches that offer psychological rehabilitation in community settings can be effective in reducing recidivism and aggressive behavior and can increase individual and community resilience.

$\rightarrow$ Reintegration programs for adult male extremists should, from as early as possible, work with individuals embedded in their communities, not in detention settings.

$\rightarrow$ Strategic frameworks for P/CVE and the reintegration of former violent extremists should mandate and resource research, including a review of best practices from similar fields, and capacity building and education of civil society and government actors.

\section{Context}

Violent extremism has a trauma problem. Psychological trauma plays a role in the genesis, perpetration, and resolution of violent extremism. ${ }^{1}$ Despite evidence attesting to the positive effects of trauma-informed rehabilitation programs and trauma recovery support for armed combatants and criminal offenders, ${ }^{2}$ there

1 Daniel Koehler, "Violent extremism, mental health and substance abuse among adolescents: towards a trauma psychological perspective on violent radicalization and deradicalization," The Journal of Forensic Psychiatry \& Psychology 31, no. 3 (2020): 455-472, https://doi.org/10.1080/14789949.2020.1758752; Michael Niconchuk, "Terrorist Cells: The Neurobiology and Violent Extremism," in NeuroPeace, no. 1, ed. Colette Rausch (Arlington, VA: Mary Hoch Center for Reconciliation, 2016), 57-86.

2 Anna Maedl, et al., "Psychological rehabilitation of ex-combatants in non-western, post-conflict settings," In Trauma rehabilitation after war and conflict, ed. Erin Martz (New York: Springer, 2010); Theo Gavrielides, ed., The psychology of restorative justice: Managing the power within (Abingdon: Routledge, 2016). 
has been limited donor interest or coordinated policy effort to meaningfully integrate trauma recovery into the design of rehabilitation and reintegration of violent extremists specifically.

While there is no established causal link between trauma exposure and radicalization into violent extremism, ${ }^{3}$ chronic stress and trauma can affect gene expression, cognitive development, moral reasoning, impulse control, attitudes, emotion regulation, and risk of substance abuse in ways that can contribute - through interaction with environmental factors - to violent behavior or facilitate attraction to violent extremist groups. ${ }^{4}$ It is thus no surprise that various researchers have found elevated rates of childhood adversity and trauma exposure among samples of violent extremists. ${ }^{5}$ For example, Simi and colleagues found that more than $40 \%$ of white supremacists interviewed had experienced childhood abuse, ${ }^{6}$ and research into police files from the Netherlands found disproportionately high levels of post-traumatic stress disorder (PTSD) among Dutch foreign fighters who traveled to the Middle East. ${ }^{7}$

Research in global mental health confirms trauma is not only relevant to the emergence of violent extremism but is also a consequence of participation in violent extremism. Various studies have confirmed that men, women, and children who have lived through armed conflicts-and especially those involved in armed combat-experience elevated rates of PTSD, anxiety, depression, and other psychological and emotional disturbances as compared to the general population, and those disturbances can complicate post-conflict participation in social, educational, and job activities. ${ }^{8}$ Among violent extremists, evidence from Iraq suggests that more than $40 \%$ of child soldiers recruited into the Islamic State experienced PTSD after their disengagement, ${ }^{9}$ and interviews with adult ISIS combatants confirm abnormally high rates of trauma exposure among both male and female participants. ${ }^{10}$

Untreated trauma and chronic stress can facilitate individual radicalization into extremist violence, and participation in extremist violence increases individual exposure to trauma. Additionally, the process of disengagement and reintegration from violent extremism to civilian life is rife with potential traumatic experiences including family separation, detention, forced relocation, social stigma, discrimination, and isolation. Like other traumatic experiences, these stressors can cause adaptations in the brain and body that can, in turn, affect aspects of cognition like memory,

3 Armando Piccinni, Donatella Marazziti, and Antonello Veltri, "Psychopathology of terrorists." CNS Spectrums 23, no. 2 (2018): 142-143, https://doi.org/10.1017/S1092852917000645.

4 Niconchuk, "Terrorist Cells."

5 Paul Gill, Caitlin Clemmow, Florian Hetzel, Bettina Rottweiler, Nadine Salman, Isabelle Van Der Vegt, Zoe Marchment et al. "Systematic Review of Mental Health Problems and Violent Extremism," The Journal of Forensic Psychiatry \& Psychology 32, no. 1 (2021): 51-78; Koehler, "Violent extremism and mental health."

6 Pete Simi, Karyn Sporer, and Bryan F. Bubolz, "Narratives of childhood adversity and adolescent misconduct as precursors to violent extremism: A life-course criminological approach," Journal of research in crime and delinquency 53, no. 4 (2016): 536563, https://doi.org/10.1177/0022427815627312.

7 Anton Weenink, "Adversity, criminality, and mental health problems in Jihadis in Dutch Police files," Perspectives on Terrorism 13, no. 5 (2019): 130-142.

8 Maedl, et al., "Psychological rehabilitation."

9 Jan Ilhan Kizilhan and Michael Noll-Hussong, "Post-traumatic stress disorder among former Islamic State child soldiers in northern Iraq," The British Journal of Psychiatry 213, no. 1 (2018): 425-429, https://doi.org/10.1192/bjp.2018.88.

10 Anne Speckhard and Molly D. Ellenberg, "ISIS in Their Own Words," Journal of Strategic Security 13, no. 1 (2020): 82-127. 
information processing, and threat perception, as well as negatively affect trust, the ability to form and maintain relationships, and the ability to regulate emotions and reactions. ${ }^{11}$ Such traumainduced adaptations can, over time, compromise successful reintegration. And while there is a general dearth of data on the psychobiological markers of trauma among extremist populations specifically, the limited data we have from child recruits, as well as from other conflict-affected populations has led practitioners to call for a more prominent role of psychological rehabilitation and trauma recovery in the reintegration of violent extremists. ${ }^{12}$

\section{Relevance to Policy and Practice}

Evidence from restorative justice activities ${ }^{13}$ and disarmament, demobilization, and reintegration (DDR) of armed combatants confirm that social ecological and trauma-informed approaches that offer psychological rehabilitation in community settings can be effective in reducing recidivism and aggressive behavior and can increase individual and community resilience. ${ }^{14}$ Evidence from Sierra Leone $^{15}$ has shown that focusing on social relationships while removing barriers to integration, livelihood, local and national systems, and policy advocacy improved the reintegration success and resilience of former child soldiers. Evidence from DDR activities in Somalia and Uganda suggest that narrative therapy, used to treat trauma-related distress, reduced PTSD symptoms among former combatants, thus facilitating reintegration into home communities. ${ }^{16}$

The promotion and scaling of these types of good practices face several challenges. Even outside the realm of rehabilitation and reintegration programs, mental health and psychosocial support (MHPSS) programs face significant obstacles. These obstacles multiply when conducting MHPSS activities for former violent extremists.

Globally, mental health support constitutes less than $0.5 \%$ of international health assistance ${ }^{17}$ and only a handful of counterterrorism, DDR, or reintegration programs include financial support for MHPSS activities. While examples from DDR encourage the use of community-based MHPSS activities, security actors - who play a large role in rehabilitation efforts for violent extremistshesitate to de-securitize programs dealing with violent extremists, despite the evidence from work with non-extremist combatants. ${ }^{18}$

11 Niconchuk, "Terrorist Cells."

12 Chris Bosley, Violent Extremist Disengagement and Reconciliation: A Peacebuilding Approach (Washington D.C.: U.S. Institute of Peace, 2020), 10-16, https://www.usip.org/publications/2020/07/violent-extremist-disengagement-and-reconciliationpeacebuilding-approach; Stevan Weine, Zachary Brahmbatt, Emma Cardeli, and Heidi Ellis, "Rapid review to inform the rehabilitation and reintegration of child returnees from the Islamic State," Annals of Global Health 86, no. 1 (2020): 64, https:// doi.org/10.5334/aogh.2835.

13 Gavrielides, ed., The psychology of restorative justice.

14 Mary Beth Altier, Violent Extremist Disengagement and Reintegration: Lessons from Over 30 Years of DDR (Washington, D.C.: RESOLVE Network, 2021), https://doi.org/10.37805/vedr2021.1.

15 Theresa S. Betancourt, et al., "Stigma and Acceptance of Sierra Leone's Child Soldiers: A Prospective Longitudinal Study of Adult Mental Health and Social Functioning," Journal of the American Academy of Child \& Adolescent Psychiatry 59, no. 6 24-718:(2020), https://doi.org/10.1016/i.jaac.2019.05.026.

16 Maedl, et al., "Psychological rehabilitation."

17 Barnabas J. Gilbert, et al., "Assessing development assistance for mental health in developing countries: 2007-2013," PLoS Med 12, no. 6 (2015): 2, https://doi.org/10.1371/journal.pmed.1001834.

18 Altier, Violent Extremist Disengagement. 
Furthermore, it is not yet known to what degree the types of MHPSS interventions traditionally utilized with armed combatants and child soldiers are effective when applied to ideologicallymotivated extremist populations. That said, evidence from otherfields, such as cult deprogramming, that deal with ideologically-driven individuals suggests that, as seen in DDR programs, mental and behavioral health support is critical to the successful social reintegration of individuals who were part of counter-normative, ideologically motivated groups. ${ }^{19}$

Additionally, MHPSS services in many conflict-affected communities predominantly target women and children only, ${ }^{20}$ thus excluding adult men who comprise a significant percentage of the extremist combatant population. Additionally, many existing trauma recovery programs in conflict settings are grounded in Western cultural understandings of illness, distress, and healing. These factors potentially limit the effectiveness of many mainstream approaches in affected communities. ${ }^{21}$ Those involved in trauma recovery for extremist combatants thus have to consider how to adapt current approaches or innovate new approaches that are proven effective and attractive for adult males in non-Western contexts.

To date, there are only few models of community-based MHPSS support for former extremist combatants. While Kazakhstan, as an example, has made strides to offer MHPSS support for reintegrated extremists, their strategy has exclusively targeted women and children to date. ${ }^{22}$ On the other hand, Sri Lanka, ${ }^{23}$ the United Kingdom, ${ }^{24}$ Saudi Arabia, and Singapore ${ }^{25}$ all have varying degrees of mandated MHPSS support activities within their rehabilitation programs for adult men. However, most of these activities are offered in incarceration and detention settings and do not place men within their communities of origins, as best practice from DDR would suggest. ${ }^{26}$

19 Morgane Rousselet, Olivier Duretete, Jean Benoit Hardouin, and Marie Grall-Bronnec, "Cult membership: What factors contribute to joining or leaving?," Psychiatry research 257 (November 2017): 27-33, https://doi.org/10.1016/j.psychres.2017.07.018; Chantal Kern and Johannes Jungbauer, "Long-Term Effects of a Cult Childhood on Attachment, Intimacy, and Close Relationships: Results of an In-Depth Interview Study," Clinical Social Work Journal (October 2020): 1-11, https:// doi.org/10.1007/s10615-020-00773-w.

20 Anita L. Kisilu and Lina Darras, "Highlighting the gender disparities in mental health among Syrian refugees in Jordan," Intervention 16, no. 2 (2018): 140, https://doi.org/10.4103/INTV.INTV 1818.

21 Ethan Watters, Crazy like us: The globalization of the American psyche (New York: Simon and Schuster, 2010).

22 Julie Coleman and Teuta Avdimetaj, What EU Member States can learn from Kosovo's experience in repatriating former foreign fighters and their families (The Hague: Clingendael Institute, 2020), 3-4, https://www.clingendael.org/sites/default/ files/2020-06/Policy Brief Kosovo experience repatriating former foreign fighters May 2020.pdf; Weine, et al., "Rapid review to inform the reintegration of child returnees," 64.

23 David Webber, et al., "Deradicalizing detained terrorists," Political Psychology 39, no. 3 (2018): 540-42, https://doi. org/10.1111/pops.12428.

24 Helen Lewis, "Why Extremists Need Therapy," The Atlantic, February 11, 2020, https://www.theatlantic.com/international/ archive/2020/02/britain-london-terrorism-deradicalization/606376/.

25 Webber, et al., "Deradicalizing detained terrorists," 541-42.

26 Altier, Violent Extremist Disengagement; Maedl, et al., "Psychological rehabilitation." 


\section{Recommendations}

\section{Adapt social ecological and trauma recovery approaches to rein- tegration efforts for former violent extremists}

Evidence from DDR activities with child soldiers and civil conflict combatants shows that traumainformed social ecological models that incorporate family, community, religious, and policy support as well as community understandings of safety, security, and peace are most effective in ensuring positive outcomes for individuals and communities. ${ }^{27}$ For example, Sierra Leone's DDR activities for child soldiers ${ }^{28}$ placed significant focus on educational support, rituals and religious practices, and family reunification to improve social integration and acceptance of former child soldiers in the long term, while noting that high levels of trauma exposure pose a challenge to positive social trajectories even with strong social and community support. ${ }^{29}$

National governments should incorporate social ecological models at the foundations of reintegration activities for those affiliated with violent extremist groups. For example, Weine and colleagues propose a framework for rehabilitation and reintegration of women and children returning from ISIS territory that leverages best practices from work with child soldiers. They offer a model of individual mental health support, family support, educational support, and public safety, where security services act as referral and consultation partners for activities offered mostly in community settings. ${ }^{30}$ The governments of Kazakhstan, Kosovo, and the Republic of North Macedonia made initial steps in 2019 and 2020 to realize such programs.

\section{Innovate and scale effective trauma recovery services for adult male violent extremists}

Most current repatriation and reintegration programs for violent extremists exclude or limit men given security concerns. The deradicalization efforts that do target men and incorporate MHPSS often do so only in detention settings, focusing on individual behavior change while ignoring the context the individual came from and will return to. ${ }^{31}$

27 Theresa S. Betancourt, et al., "Addressing mental health disparities in refugee children through family and community-based prevention," In Humanitarianism and mass migration: Confronting the world crisis, ed. Marcelo Suarez-Orozco (Berkeley: University of California Press, 2019), 138-41; Theresa S. Betancourt, et al., "Adolescents and Armed Conflict," In Handbook of Adolescent Development Research and Its Impact on Global Policy, eds. Jennifer E Lansford and Prerna Banati (Oxford: Oxford University Press, 2018), 199-213.

28 John Williamson, "The disarmament, demobilization and reintegration of child soldiers: social and psychological transformation in Sierra Leone," Intervention: International Journal of Mental Health, Psychosocial Work \& Counselling in Areas of Armed Conflict 4, no. 3 (2006): 194-201, https://doi.org/10.1097/WTF.0b013e328011a7fb.

Betancourt, et al., "Stigma and Acceptance of Sierra Leone's Child Soldiers," 721-24.

Weine, et al., "Rapid review to inform the reintegration of child returnees," 64.

31

John Horgan and Mary Beth Altier, "The future of terrorist de-radicalization programs," Georgetown Journal of International Affairs 13, no. 2 (2012): 85-88. https://www.jstor.org/stable/43134238; Bosley, Violent Extremist Disengagement and Reconciliation, 10-16; Michael Niconchuk, "A Dangerous Displacement Crisis: The Psychological Ecology of Extremism After the Fall 
Effective mental health and trauma recovery for violent extremist men requires more than the inclusion of counselors or therapists into activities in incarceration settings. Reintegration programs for adult male extremists should, from as early as possible, work with individuals embedded in their communities, not in detention settings.

More broadly, civil society organizations should increase efforts to develop effective activities for adult male former violent extremists that address stigma, gender norms around mental health care, and security concerns around divulging personal information. Two programs of note in the Middle East working with male refugees-The Field Guide for Barefoot Psychology and Tell Your Story $^{32}$ - have been effective in improving emotion regulation and healthy behaviors in adult men, including some involved in armed conflict, by using storytelling and self-taught exercises outside of clinical settings. These programs have been effective largely because they reduce the need to disclose personal stories and experiences, instead relying on realistic but fictional narratives accompanied by exercises that are self-taught and self-paced. Of note, any approach must be carefully tailored to the context of former violent extremists, as ideological convictions may cause participants to view certain therapeutic approaches with skepticism or hostility. For example, certain Muslim and Christian communities may reject the use of yoga treatments because of its ties to Hindu scripture and practice. ${ }^{33}$

\section{Generate new data on the links between trauma and security outcomes while empowering local researchers}

National governments and security actors do not always know what literature should inform their efforts nor where to access this literature. Additionally, deradicalization, reintegration, and community mental health efforts use different definitions and outcome measures that make it difficult to study exactly if and how changes in mental health, trauma, and individual psychosocial factors affect peacebuilding outcomes such as community resilience, social capital, and conflict reduction.

First, national guidelines and strategic frameworks for P/CVE and the reintegration of former violent extremists should mandate and resource research, including a review of best practices from similar fields, and capacity building and education of civil society and government actors. Capacity building should incorporate both local and international experts who can share experiences, expertise, and evidence from other contexts to guide initial design of locally relevant models and indicators. ${ }^{34}$

of ISIS," in Terrorism, Radicalisation \& Countering Violent Extremism, ed. Shashi Jayakumar (Singapore: Palgrave Pivot, 2019), 81-99.

32 Angela Nickerson, et al., "'Tell Your Story': a randomized controlled trial of an online intervention to reduce mental health stigma and increase help-seeking in refugee men with posttraumatic stress," Psychological medicine 50, no. 5 (2020): 782-90, https://doi.org/10.1017/S0033291719000606; Vivian Khedari, Story, Science, and Self-Care in a Refugee Community: Initial Impact of The Field Guide for Barefoot Psychology (Boston, MA: Beyond Conflict, 2020).

33 Mohammad Tariqur Rahman, Reeza Nazer, Lindsay Brown, Ibrahim Shogar, and Anke Iman Bouzenita, "Therapeutic Interventions: an Islamic Perspective," Journal of the Islamic Medical Association of North America 40, no. 2 (2008): 60, https://doi. org/10.5915/40-2-4447.

34 Graham Thornicroft, Tanya Deb, and Claire Henderson, "Community mental health care worldwide: current status and further developments," World Psychiatry 15, no. 3 (2016): 278-82, https://doi.org/10.1002/wps.20349. 
Second, program design should integrate affected community members and local researchers as early as possible in order to both improve local research capacities and promote the incorporation of indicators that are relevant and meaningful locally. ${ }^{35}$ Specifically, calls for proposals and national frameworks should mandate participatory research approaches and the incorporation of local researchers and academics in program design and the capacity building of civil society and government actors.

Third, funding agencies should support innovative applied research that bridges disciplines that do not traditionally work together to better understand the links between mental health, trauma exposure, and peacebuilding outcomes. Existing norms in academia complicate the generation of this type of data. For example, political science research often requires large sample sizes in order to sufficiently power cohort or field studies, whereas clinical psychology or psychophysiology require more resource-intensive and invasive measures and can sufficiently power findings with smaller sample sizes. Ideally, research into the links between individual mental health factors and peacebuilding outcomes could neatly track interactions between individual-level changes in biomarkers, physiological indicators, and trauma-related symptoms while also exploring larger trends at the community level. The need for evidence-based programming should sit alongside support for innovative and non-traditional research that can potentially reveal new and effective approaches. ${ }^{36}$

\section{Conclusion}

Chronic stress and trauma are both catalyst and consequence of violent extremism. Individual level psychosocial factors interact with relationships, social and political environments, and policies to catalyze individual and collective action towards or away from violence. To successfully demobilize, reintegrate, and rehabilitate former violent extremists, programs must address the issue of trauma and offer community-based psychosocial support that integrates and follows individuals within their community context and offers similar supportive activities to members of the receiving community. To a certain extent, countries' willingness to commit to the trauma recovery of reintegrated violent extremists requires admitting that policies and communities often play a role in erecting the scaffolding towards violence by fomenting grievance, creating exclusion, and perpetrating injustice. The meaningful integration of trauma recovery in the reintegration of violent extremists thus forces the difficult realization that mental health reflects the condition of our communities and our failures to support members of our own society.

35 Pamina Firchow, Reclaiming everyday peace: Local voices in measurement and evaluation after war (Cambridge: Cambridge University Press, 2018).

36 Elizabeth Hume, Jessica Baumgardner-Zuzik, Conor Seyle, Eric Keels, and Dianna E. Almanza, Getting from Here to There: Successful implementation of the Global Fragility Act (Alliance for Peacebuilding, July 2020), 9-22, https://www.allianceforpeacebuilding.org/afp-publications/getting-from-here-to-there. 


\section{Suggested further readings}

\section{Trauma and Chronic Stress}

McEwen, Bruce S. "Neurobiological and systemic effects of chronic stress." Chronic stress 1 (2017): 2470547017692328. https:// doi.org/10.1177/2470547017692328.

Van der Kolk, Bessel. The body keeps the score: Mind, brain and body in the transformation of trauma. UK: Penguin, 2014.

\section{Global Mental Health}

Kohrt, Brandon A., Katherine Ottman, Catherine Panter-Brick, Melvin Konner, and Vikram Patel. "Why we heal: The evolution of psychological healing and implications for global mental health." Clinical Psychology Review 82 (2020): 101920. https://doi. org/10.1016/j.cpr.2020.101920.

Patel, Vikram, Shekhar Saxena, Crick Lund, Graham Thornicroft, Florence Baingana, Paul Bolton, Dan Chisholm et al. "The Lancet Commission on global mental health and sustainable development." The Lancet 392, no. 10157 (2018): 1553-1598.

Watters, Ethan. Crazy like us: The globalization of the American psyche. Simon and Schuster, 2010.

\section{Mental Health and Violent Extremism}

Koehler, Daniel. "Violent extremism, mental health and substance abuse among adolescents: towards a trauma psychological perspective on violent radicalization and deradicalization." The Journal of Forensic Psychiatry \& Psychology 31, no. 3 (2020): 455-472. https://doi.org/10.1080/14789949.2020.1758752.

Niconchuk, Michael. "Terrorist Cells: The Neurobiology and Violent Extremism." In NeuroPeace, no. 1, edited by Colette Rausch, 57-86. Arlington, VA: Mary Hoch Center for Reconciliation, 2016.

Weine, Stevan, Zachary Brahmbatt, Emma Cardeli, and Heidi Ellis. "Rapid review to inform the rehabilitation and reintegration of child returnees from the Islamic State." Annals of global health 86, no. 1 (2020). https://doi.org/10.5334/aogh.2835.

\section{Trauma Recovery in Post-Conflict Environments}

Ellis, B. Heidi, Jeffrey P. Winer, Kate Murray, and Colleen Barrett. "Understanding the mental health of refugees: Trauma, stress, and the cultural context." In The Massachusetts General Hospital Textbook on Diversity and Cultural Sensitivity in Mental Health, edited by Ranna Parekh and Nhi-Ha T. Trinh, 253-273. Humana Press, 2019. https://doi.org/13 6-20174-030-3-978/10.1007.

Maedl, Anna, Elisabeth Schauer, Michael Odenwald, and Thomas Elbert. "Psychological rehabilitation of ex-combatants in nonwestern, post-conflict settings." In Trauma rehabilitation after war and conflict, edited by Erin Martz, 177-213. New York: Springer, 2010.

Ventevogel, Peter. "Interventions for mental health and psychosocial support in complex humanitarian emergencies: moving towards consensus in policy and action?." Mental Health of Refugee and Conflict-Affected Populations, edited by Nexhmedin Morina and Angela Nickerson, 155-180. New York: Springer, 2018. https://doi.org/8 2-97046-319-3-978/10.1007. 


\section{Bibliography}

Altier, Mary Beth. Violent Extremist Disengagement and Reintegration: Lessons from Over 30 Years of DDR. Washington, D.C.: RESOLVE Network, 2021. https://doi.org/10.37805/vedr2021.1.

Betancourt, Theresa S., Stephanie Zuilkowski, Emily Coles, Katharine Collet, and Musu Jambai. "Adolescents and Armed Conflict." In Handbook of Adolescent Development Research and Its Impact on Global Policy, edited by Jennifer EE Lansford and Prerna Banati, 196-215. Oxford: Oxford University Press, 2018.

Betancourt, Theresa S., Rochelle L. Frounfelker, Jenna M. Berent, Bhuwan Gautam, Saida Abdi, Abdirahman Abdi, Zahara Haji, Ali Maalim, and Tej Mishra. "Addressing mental health disparities in refugee children through family and community-based prevention." In Humanitarianism and mass migration: Confronting the world crisis, edited by Marcelo Suarez-Orozco, 137-64. Berkeley: University of California Press, 2019.

Betancourt, Theresa S., Dana L. Thomson, Robert T. Brennan, Cara M. Antonaccio, Stephen E. Gilman, and Tyler J. VanderWeele. "Stigma and Acceptance of Sierra Leone's Child Soldiers: A Prospective Longitudinal Study of Adult Mental Health and Social Functioning." Journal of the American Academy of Child \& Adolescent Psychiatry 59, no. $26-715$ :(2020) 6. https://doi. org/10.1016/j.jaac.2019.05.026.

Bosley, Chris. Violent Extremist Disengagement and Reconciliation: A Peacebuilding Approach. Washington D.C.: U.S. Institute of Peace, 2020. https://www.usip.org/publications/2020/07/violent-extremist-disengagement-and-reconciliation-peacebuilding-approach.

Coleman, Julie, and Teuta Avdimetaj. What EU Member States can learn from Kosovo's experience in repatriating former foreign fighters and their families. The Hague: Clingendael Institute, 2020. https://www.clingendael.org/sites/default/files/2020-06/ Policy Brief Kosovo experience repatriating former foreign fighters May 2020.pdf.

Firchow, Pamina. Reclaiming everyday peace: Local voices in measurement and evaluation after war. Cambridge: Cambridge University Press, 2018.

Gavrielides, Theo, ed. The psychology of restorative justice: Managing the power within. Abingdon: Routledge, 2016.

Gilbert, Barnabas J., Vikram Patel, Paul E. Farmer, and Chunling Lu. "Assessing development assistance for mental health in developing countries: 2007-2013." PLoS Med 12, no. 2015) 6): e1001834, https://doi.org/10.1371/journal.pmed.1001834.

Gill, Paul, Caitlin Clemmow, Florian Hetzel, Bettina Rottweiler, Nadine Salman, Isabelle Van Der Vegt, Zoe Marchment, et al. "Systematic Review of Mental Health Problems and Violent Extremism." The Journal of Forensic Psychiatry \& Psychology 32, no. $78-51: 2021) 1$.

Horgan, John, and Mary Beth Altier. "The future of terrorist de-radicalization programs." Georgetown Journal of International Affairs 13, no. 90-83:(2012) 2. https://www.jstor.org/stable/43134238.

Hume, Elizabeth, Jessica Baumgardner-Zuzik, Conor Seyle, Eric Keels, and Dianna E. Almanza. Getting from Here to There: Successful implementation of the Global Fragility Act. Alliance for Peacebuilding, July 2020. https://www.allianceforpeacebuilding. org/afp-publications/getting-from-here-to-there.

Khedari, Vivian. Story, Science, and Self-Care in a Refugee Community: Initial Impact of The Field Guide for Barefoot Psychology. Boston, MA: Beyond Conflict, 2020.

Kern, Chantal, and Johannes Jungbauer. "Long-Term Effects of a Cult Childhood on Attachment, Intimacy, and Close Relationships: Results of an In-Depth Interview Study." Clinical Social Work Journal (October 11-1:(2020. https://doi.org/10.1007/ s-00773-020-10615w. 
Kisilu, Anita L., and Lina Darras. "Highlighting the gender disparities in mental health among Syrian refugees in Jordan." Intervention 16, no. 146-140:(2018) 2. https://doi.org/10.4103/INTV.INTV 1818.

Kizilhan, Jan Ilhan, and Michael Noll-Hussong. "Post-traumatic stress disorder among former Islamic State child soldiers in northern Iraq." The British Journal of Psychiatry 213, no. 429-425:(2018) 1. https://doi.org/10.1192/bjp.2018.88.

Koehler, Daniel. "Violent extremism, mental health and substance abuse among adolescents: towards a trauma psychological perspective on violent radicalization and deradicalization." The Journal of Forensic Psychiatry \& Psychology 31, no. :(2020) 3 472-455. https://doi.org/10.1080/14789949.2020.1758752.

Lewis, Helen. "Why Extremists Need Therapy." The Atlantic, February 11, 2020. https://www.theatlantic.com/international/ archive/2020/02/britain-london-terrorism-deradicalization/606376/.

Maedl, Anna, Elisabeth Schauer, Michael Odenwald, and Thomas Elbert. "Psychological rehabilitation of ex-combatants in nonwestern, post-conflict settings." In Trauma rehabilitation after war and conflict, edited by Erin Martz, 177-213. New York: Springer, 2010

Nickerson, Angela, Yulisha Byrow, Rosanna Pajak, Tadgh McMahon, Richard A. Bryant, Helen Christensen, and Belinda J. Liddell. "'Tell Your Story': a randomized controlled trial of an online intervention to reduce mental health stigma and increase helpseeking in refugee men with posttraumatic stress." Psychological medicine 50, no. 92-781:(2020) 5. https://doi.org/10.1017/ $\underline{\text { s0033291719000606. }}$

Niconchuk, Michael. "Terrorist Cells: The Neurobiology and Violent Extremism." In NeuroPeace, no. 1, edited by Colette Rausch, 57-86. Arlington, VA: Mary Hoch Center for Reconciliation, 2016.

Niconchuk, Michael. "A Dangerous Displacement Crisis: The Psychological Ecology of Extremism After the Fall of ISIS." In Terrorism, Radicalisation \& Countering Violent Extremism, edited by Shashi Jayakumar, 81-99. Singapore: Palgrave Pivot, 2019.

Piccinni, Armando, Donatella Marazziti, and Antonello Veltri. "Psychopathology of terrorists." CNS Spectrums 23, no. 2 (2018): 141-144. https://doi.org/10.1017/S1092852917000645.

Rahman, Mohammad Tariqur, Reeza Nazer, Lindsay Brown, Ibrahim Shogar, and Anke Iman Bouzenita. "Therapeutic Interventions: an Islamic Perspective." Journal of the Islamic Medical Association of North America 40, no. 60 :(2008) 2. https://doi. org/4447-2-40/10.5915.

Rousselet, Morgane, Olivier Duretete, Jean Benoit Hardouin, and Marie Grall-Bronnec. "Cult membership: What factors contribute to joining or leaving?.” Psychiatry research 257 (November 33-27 :(2017. https://doi.org/10.1016/j.psychres.2017.07.018.

Simi, Pete, Karyn Sporer, and Bryan F. Bubolz. "Narratives of childhood adversity and adolescent misconduct as precursors to violent extremism: A life-course criminological approach." Journal of research in crime and delinquency 53, no. -536:(2016 4 563. https://doi.org/10.1177/0022427815627312.

Speckhard, Anne, and Molly D. Ellenberg. "ISIS in Their Own Words." Journal of Strategic Security 13, no. $127-82$ :(2020) 1.

Thornicroft, Graham, Tanya Deb, and Claire Henderson. "Community mental health care worldwide: current status and further developments." World Psychiatry 15, no. 86-276:(2016) 3. https://doi.org/10.1002/wps.20349.

Watters, Ethan. Crazy like us: The globalization of the American psyche. New York: Simon and Schuster, 2010.

Webber, David, Marina Chernikova, Arie W. Kruglanski, Michele J. Gelfand, Malkanthi Hettiarachchi, Rohan Gunaratna, MarcAndre Lafreniere, and Jocelyn J. Belanger. "Deradicalizing detained terrorists." Political Psychology 39, no. 556-539: 2018) 3. https://doi.org/10.1111/pops.12428.

Weenink, Anton. "Adversity, criminality, and mental health problems in Jihadis in Dutch Police files." Perspectives on Terrorism 13, no. $142-130:(2019) 5$. 
Weine, Stevan, Zachary Brahmbatt, Emma Cardeli, and Heidi Ellis. "Rapid review to inform the rehabilitation and reintegration of child returnees from the Islamic State." Annals of Global Health 86, no. 64 :(2020) 1. https://doi.org/10.5334/aogh.2835.

Williamson, John. "The disarmament, demobilization and reintegration of child soldiers: social and psychological transformation in Sierra Leone." Intervention: International Journal of Mental Health, Psychosocial Work \& Counselling in Areas of Armed Conflict 4, no. 3 (2006): 185-205. https://doi.org/10.1097/WTF.0b013e328011a7fb 


\section{About the Note}

Author: Michael Niconchuk

Michael Niconchuk is an applied neuroscience researcher and practitioner focusing on trauma recovery in conflict-affected populations and the relationship between trauma and intergroup violence. Mike is the Program Director for Trauma \& Violent Conflict at Beyond Conflict as well as the Senior Technical Expert for Mental Health and Psychosocial Support at Questscope in Amman, Jordan. Based in Jordan, Mike oversees the design and implementation of research projects that address the role of chronic stress and trauma in the genesis and escalation of violent conflict and the role of trauma recovery in conflict resolution efforts. Michael is the author of several innovative scientific publications on issues of neuroscience, violent extremism, and intergroup conflict and of the Field Guide for Barefoot Psychology, a psychoeducation program for communities affected by trauma and forced displacement. Michael is a former Fulbright Scholar and holds degrees from Tufts University and University College London.

The views expressed in this publication are those of the authors. They do not necessarily reflect the views of the RESOLVE Network, the U.S. Institute of Peace, or any entity of the U.S. government.

RESOLVE NETWORK

better research.informed practice.improved policy on violent extremism.

www.resolvenet.org

y $f$ in. 